\title{
Uji Aktivitas Ekstrak Etanol 70\% Daun Ketapang (Terminalia catappa L.) Pada Hamster Syrian Jantan Hiperglikemia Dan Hiperkolesterolemia Dengan Parameter Pengukuran Kolesterol Total Dan LDL
}

\author{
Maharadingga a, ${ }^{\star}$, Ani Pahriyani ${ }^{a, 2}$, Desilva Arista ${ }^{\text {a, }} 3$ \\ a Fakultas Farmasi dan Sains, Universitas Muhammadiyah Prof. DR Hamka, Jakarta \\ maharadingga@uhamka.ac.id* \\ *korespondensi penulis \\ INFO ARTIKEL

\section{ABSTRAK}

Diterima :

I4-06-2021

Disetujui :

I2-07-202I

\section{Kata kunci:}

Daun ketapang;

Hiperglikemia;

Hiperkolesterolemia;

Kolesterol total;

LDL.
Daun ketapang mengandung beberapa senyawa aktif seperti flavonoid, saponin, tanin, alkaloid, fenol dan triterpen. Senyawa flavonoid adalah salah satu senyawa polifenol yang memiliki efek antihiperkolesterolemia. Penelitian ini bertujuan untuk mengetahui aktivitas ekstrak etanol 70\% daun ketapang (Terminalia catappa L.) dalam menurunkan kadar kolesterol total dan LDL darah pada hamster syrian jantan hiperkolesterolemia dan hiperglikemia. Hewan uji dibagi 6 kelompok perlakuan, masing-masing kelompok terdiri dari 4 ekor hamster, yaitu kontrol normal, kontrol positif (atorvastatin), kontrol negatif, Kontrol Uji (KU) I, II, dan III. Pemberian ekstrak dan atorvastatin selama I 4 hari setelah induksi pakan tinggi lemak dan aloksan. Hasil uji ANOVA satu arah menunjukkan adanya perbedaan setelah perlakuan. Selanjutnya dilakukan uji Tukey yang menunjukkan KU III (Dosis $\mathrm{I} 20 \mathrm{mg} / \mathrm{Kg} \mathrm{BB}$ ) memiliki persentase terbesar dalam penurunan kadar kolesterol total dan LDL, namun tidak sebanding dengan kontrol positif. Kesimpulan, ekstrak etanol $70 \%$ daun ketapang aktif dalam menurunkan kolesterol total dan LDL namun tidak lebih baik dari atorvastatin

Key word:

Ketapang leaf;

Hyperglycemia;

Hypercholesterolemia

Total cholesterol;

LDL.

\section{ABSTRACT}

Ketapang leaves contain amount of active compounds such flavonoids, saponins, tannins, alkaloids, phenols and triterpenes. Flavonoids are polyphenolic compounds that have an anti-hypercholesterolemia effect. This study aimed to find the activities of $70 \%$ ketapang leaf (Terminalia catappa L.) ethanolic extract in reducing level of LDL and total cholesterol in male Syrian hypercholesterolemia and hyperglycemia hamsters. Animals was devided into 6 treatment groups, each group consisted of 4 hamsters, namely normal control, positive control (atorvastatin), negative control, Test Control (TC) I, II, and III. Treatment was done by giving extracts and atorvastatin for I4 days after induction of high-fat and alloxan feed. The results of the one-way ANOVA test showed differences after treatment. Then the Tukey test has performed which showed that TC III (Dose of $120 \mathrm{mg} / \mathrm{Kg} \mathrm{BB}$ ) had the largest percentage in decreasing total cholesterol and LDL levels, but not comparable with positive controls. In conclusion, $70 \%$ ketapang leaf ethanolic extracts was active in reducing total cholesterol and LDL level but were not higher than atorvastatin.

This is an open access article under the CC-BY-SA license. 


\section{Pendahuluan}

Diabetes Mellitus (DM) adalah sekumpulan dari gangguan metabolik yang ditandai oleh hiperglikemi dan abnormalitas metabolisme dari karbohidrat, lemak dan protein. Semua hal di atas merupakan hasil dari kerusakan sekresi insulin baik mutlak atau relatif, dan berkurangnya sensitivitas jaringan terhadap insulin dan keduanya (Priyanto, 2009).

Pada penderita DM memiliki kecenderungan mengidap hiperkolesterolemia. Hiperkolesterolemia adalah peningkatan kadar kolesterol di dalam darah, kondisi ini terjadi pada saat konsentrasi kolesterol total serum melebihi batas normal (Guyton and Hall, 2008). Penelitian oleh Uttra (20II) menunjukkan sebanyak $72 \%$ pasien DM mengalami kelainan profil lipid, yaitu peningkatan kadar trigliserida dan kolesterol total darah.

Pengobatan dengan memanfaatkan bahan alam dapat menjadi langkah alternatif dan penunjang untuk pengobatan dan pemeliharaan kesehatan pada pasien penderita hiperkolesterolemia dan hiperglikemia, salah satunya daun ketapang (Terminalia catappa L.) yang telah terbukti secara empiris (Suhono, 2010).

Ketapang diketahui memiliki banyak manfaat untuk kesehatan. Daun ketapang telah lama digunakan oleh masyarakat Asia untuk mengobati dermatitis dan hepatitis (Kinoshita et al., 2006). Ekstrak daun ketapang menunjukkan efek antiinflamasi, antioksidan dan juga berperan sebagai hepatoprotektor. Beberapa tahun terakhir ketapang pun banyak diteliti khasiat medisnya, terutama perannya sebagai antikanker dan efeknya untuk pencegahan diabetes (Divya and Vijaya, 2014).

Pada penelitian Waluyo dan Wahyuni (2017) menyatakan bahwa ekstrak etanol daun ketapang dengan dosis $2 \mathrm{mg} / 20 \mathrm{~g} \mathrm{BB}$ pada mencit yang diinduksi lemak babi secara oral sebanyak I\% dari berat mencit dapat menurunkan kadar kolesterol darah dengan persentase penurunan $42,37 \%$. Penelitian lainnya menyatakan bahwa ekstrak etanol daun ketapang mampu menurunkan kadar glukosa darah pada mencit dengan dosis $50 \mathrm{mg} / \mathrm{kg} \mathrm{BB}$ (Istiqomah, 2016).

Daun ketapang mengandung flavonoid, saponin, terpenoid dan tanin. Senyawa flavonoid adalah salah satu senyawa polifenol yang memiliki efek antihiperkolesterolemia (Waluyo dan
Wahyuni, 2017), dan sebagai antidiabetes (Istiqomah, 2016).

Berdasarkan hal di atas, maka penelitian tentang daun ketapang ini perlu dikembangkan, salah satunya sebagai antihiperkolesterolemia pada hamster dengan patologi hiperglikemia dan hiperkolesterolemia. Penelitian ini menggunakan ekstrak daun ketapang dengan pelarut etanol $70 \%$. Adanya kandungan senyawa dalam daun ketapang yang banyak maka dilakukan penyarian dengan metode maserasi. Penelitian ini bertujuan untuk mengetahui aktivitas ekstrak etanol 70\% daun ketapang (Terminalia catappa L.) dalam menurunkan kadar kolesterol total dan LDL darah pada hamster syrian jantan hiperkolesterolemia dan hiperglikemia.

\section{Metode}

\section{Alat dan Bahan}

Alat yang digunakan adalah kandang hamster beserta tempat makanan dan minuman, blender, timbangan hewan, timbangan analitik (Ohaus), ayakan no. 40, vacuum rotary evaporator (Eyela), pipa kapiler, microtube, alat suntik, centrifuge (Eppendorf), vortex (Gemmy), mikropipet (Eppendorf), spektrofotometer klinikal dan peralatan lainnya.

Bahan yang digunakan adalah Daun ketapang (Terminalia catappa L.) yang diperoleh dari Balai Penelitian Tanaman Obat dan Aromatik (BALITTRO) Bogor dan dideterminasi di Herbarium Bogoriense, Pusat Penelitian Biologi-LIPI Cibinong. Bahan kimia diantaranya adalah etanol $70 \%$, aquadest, metanol, pereaksi Mayer, pereaksi Dragendorff, pereaksi Liebermann-Burchard, asam asetat anhidrat, eter, $\mathrm{HCl}$, logam $\mathrm{Mg}, \mathrm{NaCl}, \mathrm{Na}-\mathrm{CMC}$, $\mathrm{H}_{2} \mathrm{SO}_{4}$, reagen kit kolesterol dan LDL, ketamin.

Bahan pembanding yang digunakan adalah Atorvastatin. Bahan penginduksi hiperkolesterolemia berupa pakan tinggi lemak, dan penginduksi hiperglikemia yaitu aloksan. Hewan uji yang digunakan adalah Hamster Syrian jantan (Mesocricetus auratus) umur 3-4 bulan dengan bobot badan $\pm 50-100 \mathrm{~g}$ sebanyak 24 ekor, yang dibagi ke dalam 6 kelompok yaitu kontrol negatif, kontrol positif, kontrol normal, kelompok dosis I, 2 dan 3.

\section{Pembuatan Simplisia dan Ekstrak Etanol 70\% Daun Ketapang}

Pembuatan simplisia daun ketapang dilakukan dengan mengumpulkan daun ketapang, lalu disortasi basah untuk memisahkan kotoran- 
kotoran atau bahan-bahan asing lainnya dari bahan simplisia dan dicuci bersih untuk menghilangkan tanah dan pengotor lainnya yang melekat pada bahan simplisia. Selanjutnya dirajang untuk mempermudah proses pengeringan, pengepakan dan penggilingan. Kemudian dikeringkan dengan tujuan untuk mendapatkan simplisia yang tidak mudah rusak, sehingga dapat disimpan dalam waktu yang lebih lama. Setelah itu dilakukan sortasi kering untuk memisahkan benda-benda asing yang masih tertinggal pada simplisia kering. Kemudian diayak dengan pengayak no. 40 lalu ditimbang (Depkes 1985). Pembuatan ekstrak daun ketapang dilakukan dengan cara maserasi. Serbuk kering simplisia dimasukkan ke dalam maserator, ditambahkan pelarut etanol $70 \%$ dan direndam selama 6 jam sambil sekali-sekali diaduk agar dan didiamkan selama I8 jam. Maserat dipisahkan dengan cara filtrasi, proses penyarian diulangi sebanyak tiga kali dengan jenis dan jumlah pelarut yang sama. Maserat yang diperoleh dipekatkan dengan vacuum rotary evaporator hingga diperoleh ekstrak kental (Depkes 2008).

\section{Pemeriksaan Karakteristik Ekstrak}

Pemeriksaan karakteristik ekstrak meliputi pemeriksaan organoleptik yang meliputi warna, bentuk, bau dan rasa terhadap ekstrak, penetapan kadar air, penetapan kadar abu dan perhitungan $\%$ rendemen ekstrak.

\section{Penapisan Fitokimia}

Penapisan fitokimia ekstrak daun ketapang dilakukan untuk mengetahui dan mengidentifikasi kandungan kimia yang terdapat pada ekstrak etanol 70\% daun ketapang.

\section{Persiapan Hewan Uji}

Rancangan penelitian berupa Rancangan Acak Lengkap (RAL) menggunakan rumus Federer (I963), yaitu :

$(\mathrm{t}-\mathrm{I})(\mathrm{n}-\mathrm{I}) \geq \mathrm{I} 5$

Maka hewan uji yang digunakan dalam penelitian ini adalah 24 ekor yang dibagi menjadi 6 kelompok yang masing-masing terdiri dari 4 ekor.

\section{Aklimatisasi Hewan Uji}

Hewan uji diaklimatisasi terlebih dahulu di dalam kandang selama kurang lebih tujuh hari dengan tujuan hewan uji mampu beradaptasi dengan lingkungan yang baru (Dachriyanus, 2007).

\section{Perhitungan Dosis}

Dosis ekstrak daun ketapang yang diberikan selama I4 hari yang dapat menurunkan kadar kolesterol darah terbesar pada mencit adalah pada dosis $2 \mathrm{mg} / 20 \mathrm{~g}$ BB (Waluyo dan Wahyuni, 2017), maka dosis harus dikonversikan menjadi dosis hamster. Diketahui faktor KM mencit adalah 3, dan faktor KM hamster adalah 5 (Reagan-Shaw et al., 2007).

Dosis akan dikonversikan dengan rumus sebagai berikut : Dosis mencit $=2 \mathrm{mg} / 20 \mathrm{~g} \mathrm{BB} x$ $\mathrm{I} 000=\mathrm{I} 00 \mathrm{mg} / \mathrm{Kg} \mathrm{BB}$

Dosis hamster $=$ Dosis mencit $\times(\mathrm{KM}$ mencit)/(KM hamster)

$=100 \mathrm{mg} / \mathrm{Kg} \mathrm{BB} \times 3 / 5=60 \mathrm{mg} / \mathrm{Kg} \mathrm{BB}$

Pada penelitian ini menggunakan tiga variasi dosis yaitu :

$\mathrm{KU}$ I (Dosis I); I $/ 2 \times 60 \mathrm{mg} / \mathrm{Kg} \mathrm{BB}=30 \mathrm{mg} / \mathrm{Kg}$ $\mathrm{BB}$

$\mathrm{KU}$ II (Dosis II); I $\times 60 \mathrm{mg} / \mathrm{Kg} \mathrm{BB}=60 \mathrm{mg} / \mathrm{Kg}$ $\mathrm{BB}$

$\mathrm{KU}$ III (Dosis III); $2 \times 60 \mathrm{mg} / \mathrm{Kg} \quad \mathrm{BB}=$ $\mathrm{I} 20 \mathrm{mg} / \mathrm{Kg} \mathrm{BB}$.

\section{Dosis Pembanding}

Dosis lazim atorvastatin $10-80 \mathrm{mg} /$ hari (Tallbert et al., 20I4). Dosis yang digunakan I0 mg pada manusia dewasa dengan berat badan 60 $\mathrm{kg}$ menjadi 0,167 mg/Kg BB sehingga dosis untuk hamster harus dikonversikan terlebih dahulu. Berdasarkan rumus Food and Drug Administration (FDA) dengan diketahui faktor KM manusia dewasa adalah 37 dan faktor KM hamster adalah 5 (Reagan-Shaw et al., 2007). Dosis hamster $(\mathrm{mg} / \mathrm{Kg} \mathrm{BB})=$ Dosis manusia $(\mathrm{mg} / \mathrm{Kg} \quad \mathrm{BB}) \quad \mathrm{x} \quad(\mathrm{KM}$ Manusia $) /(\mathrm{KM}$ hamster)....(3)

\section{Dosis Aloksan}

Sediaan aloksan dibuat dengan cara melarutkan 900mg aloksan dalam larutan $\mathrm{NaCl}$ 0,9\% sampai $50 \mathrm{ml}$, aduk hingga homogen. Berdasarkan hasil penelitian sebelumnya dosis I50 mg/Kg BB pada tikus mampu menaikkan kadar gula darah (Szukudelski 200I). Pada hari ke-3 pemberian aloksan \pm 12 jam setelah penyuntikan glukosa darah hamster diukur untuk melihat hasil induksi. Dosis harus dikonversikan menjadi dosis hamster. Diketahui faktor KM tikus adalah 6, dan faktor KM hamster adalah 5 (Reagan-Shaw et al., 2007).

Dosis aloksan hamster $=$ Dosis aloksan tikus $\times$ ( KM tikus)/( KM hamster) 


\section{Dosis Ketamin}

Dosis ketamin untuk anjing IO- $15 \mathrm{mg} / \mathrm{kg}$ BB (Pirade 2015). Konsentrasi ketamin yang digunakan $50 \mathrm{mg} / \mathrm{ml}$. Dosis untuk hamster harus dikonversikan terlebih dahulu berdasarkan rumus Food and Drug Administration (FDA), dengan diketahui nilai faktor KM anjing adalah 20, dan faktor KM hamster adalah 5 (Reagan-Shaw et al., 2007).

Dosis hamster $=$ Dosis anjing $\times($ Faktor KM anjing)/(Faktor KM Hamster)

\section{Pembuatan Larutan Na-CMC 0,5\%}

Kadar $\mathrm{Na}-\mathrm{CMC}$ yang dianjurkan untuk membuat larutan oral yaitu 0,I-I\% (Rowe et al., 2009). Pada penelitian ini digunakan $\mathrm{Na}-\mathrm{CMC}$ dengan konsentrasi $0,5 \%$. Sebanyak $500 \mathrm{mg} \mathrm{Na-CMC}$ ditaburkan dalam lumpang yang berisi $50 \mathrm{ml}$ aquadest panas, diaduk kuat-kuat dalam lumpang sampai terbentuk massa suspensi yang homogen, kemudian dimasukkan ke dalam labu ukur IOO $\mathrm{ml}$ dan dicukupkan volumenya sampai tanda batas.

\section{Pembuatan Sediaan Ekstrak Etanol 70\% Daun Ketapang}

Ekstrak etanol 70\% daun ketapang masingmasing dibuat sediaan suspensi dengan menambahkan larutan $\mathrm{Na}-\mathrm{CMC}$ 0,5\% hingga volume $100 \mathrm{ml}$. Volume Absorbsi Oral (VAO) yang diberikan pada hamster dari larutan tersebut dihitung dengan rumus (Purwantini,20I5): $\operatorname{VAO}(\mathrm{ml})=(\operatorname{Dosis}(\mathrm{mg} /(\mathrm{Kg})) \times \mathrm{BB}(\mathrm{Kg})) /(\mathrm{C}$ $(\mathrm{mg} / \mathrm{ml}))$

\section{Pembuatan Suspensi Atorvastatin}

Pembuatan suspensi atorvastatin dilakukan dengan cara menghaluskan tablet atorvastatin dan disuspensikan dengan Na-CMC 0,5\%. Dosis atorvastatin yang digunakan adalah $1,24 \mathrm{mg} / \mathrm{kg}$ $\mathrm{BB}$ atau $0,124 \mathrm{mg} / \mathrm{IOOg}$ BB hamster, per satu tablet atorvastatin generik mengandung $10 \mathrm{mg}$ atorvastatin. Volume suspensi yang dibuat per hari $=10 \mathrm{ml}$. Bobot satu tablet atorvastatin $304,3 \mathrm{mg}$, maka perhitungan bobot atorvastatin yang akan ditimbang berupa serbuk untuk disuspensi yaitu : Bobot atorvastatin yang ditimbang $=$ (Dosis hamster dalam 10 $\mathrm{ml}) /($ Dosis atorvastatin $) \times$ Bobot tablet $=(\mathrm{I}, 24$ $\mathrm{mg}) /(\mathrm{I} 0 \mathrm{mg}) \times 304,3 \mathrm{mg}=37,73 \mathrm{mg}$. Sehingga konsentrasi yang akan dibuat adalah 0,I24 $\mathrm{mg} / \mathrm{ml}$. Jadi satu tablet atorvastatin digerus, lalu diambil $37,73 \mathrm{mg}$ dan dimasukkan ke dalam labu ukur $10 \mathrm{ml}$, kemudian disuspensikan dengan $\mathrm{Na}$ -
CMC 0,5\% hingga tanda batas lalu dikocok sampai terdispersi homogen.

\section{Pembuatan Pakan Tinggi Lemak}

Pakan tinggi lemak dibuat dengan komposisi pakan standar 50\%, minyak $10 \%$ dan kuning telur puyuh $40 \%$. Pakan dibuat dengan cara pakan standar digerus hingga halus kemudian dicampurkan dengan kuning telur dan minyak, diaduk sampai homogen kemudian dibentuk menjadi pellet (Trimizi, 20I4). Pakan untuk satu ekor hamster dalam satu hari yaitu II g. Perhitungan pakan tinggi lemak untuk 5 kelompok hamster atau 20 ekor hamster, yaitu: 20 hamster $\times$ II g per hamster $=220 \mathrm{~g}$ Kuning telur puyuh $=40 \% \times 220 \mathrm{~g}=88 \mathrm{~g}$ Minyak $\quad=10 \% \times 220 \mathrm{~g}=22 \mathrm{~g}$ Pakan standar $\quad=50 \% \times 220 \mathrm{~g}=1 \mathrm{II} \mathrm{g}$

\section{Pengelompokkan dan Perlakuan Hewan Uji}

Penelitian dilakukan secara eksperimental dengan Rancangan Acak Lengkap (RAL), hewan uji dikelompokan menjadi 6 kelompok dengan masing-masing kelompok terdiri dari 4 ekor hamster. Pengelompokan hewan uji dilakukan dengan memberi nama setiap kelompoknya dan penyesuaian pakan yang diberikan. Kontrol normal diberi pakan standar dan Na-CMC 0,5\%, kontrol positif diberi pakan tinggi lemak, aloksan monohidrat secara ip, dan sediaan pembanding (Atorvastatin), kontrol negatif diberi pakan tinggi lemak, aloksan monohidrat secara intraperitonial (ip), dan Na-CMC 0,5\%, kontrol uji I (KU I) diberi pakan tinggi lemak, aloksan monohidrat secara ip, dan ekstrak etanol 70\% daun ketapang dosis I (30 mg/Kg BB), kontrol uji II (KU II) diberi pakan tinggi lemak, aloksan monohidrat secara ip, dan ekstrak etanol $70 \%$ daun ketapang dosis II (60 mg/ $\mathrm{Kg} \mathrm{BB})$, kontrol uji III (KU III) diberi pakan tinggi lemak, aloksan monohidrat secara ip, dan ekstrak etanol 70\% daun ketapang dosis III (I20 mg/Kg BB).

\section{Metode Pengambilan Darah}

Sebelum dilalukan pengambilan darah, hamster dibius dengan ketamin hingga tidak sadarkan diri, lalu ditusuk bagian sudut mata hamster dengan pipa kapiler, kemudian diputar pipa kapiler hingga darah mengalir. Darah ditampung pada microtube, kemudian darah diambil $2 \mathrm{ml}$ lalu disentrifugasi pada putaran $6000 \mathrm{rpm}$ selama 5 menit agar diperoleh serum, simpan darah dalam lemari es. Sampel siap dianalisis (Vogel, 2008). 


\section{Metode Pengukuran Kadar Kolesterol Total}

Pengukuran kolesterol total dilakukan dengan mengambil serum sebanyak I0 $\mu \mathrm{L}$, kemudian dicampur reagen enzim (pereaksi kolesterol kit) sebanyak $1000 \mu \mathrm{L}$, lalu dicampur dengan menggunakan alat vortex dan diinkubasi selama I0 menit pada suhu $20-25^{\circ} \mathrm{C}$ atau 5 menit pada suhu $37^{\circ} \mathrm{C}$, kemudian dibaca dengan fotometer klinikal (Human, 20I4).

\section{Metode Pengukuran Kadar LDL}

Pengukuran kadar LDL dilakukan dengan mengambil serum IO0 $\mu \mathrm{L}$, dimasukkan ke dalam microtube, ditambah $\mathrm{I} 000 \mu \mathrm{L}$ reagen pengendap LDL, kemudian dicampur dengan menggunakan alat vortex, selanjutnya larutan diinkubasi selama 5 menit dengan temperatur $37^{\circ} \mathrm{C}$, kemudian disentrifugasi selama 15 menit dan didiamkan selama I jam. Setelah itu diambil supernatan sebanyak IOO $\mu \mathrm{L}$ dimasukkan ke dalam microtube, kemudian dicampur dengan $1000 \mu \mathrm{L}$ reagen enzim (kit) kolesterol. Campuran divortex, lalu diinkubasi selama 5 menit pada suhu $37^{\circ} \mathrm{C}$. Kadar LDL kolesterol diukur dengan fotometer klinikal (Human, 20I4).

\section{Analisis Data}

Analisis data dilakukan dengan menggunakan uji normalitas dan uji homogenitas. Bila data normal dan homogen, analisis dilanjutkan dengan menggunakan metode analisis varians satu arah (one way $A N O V A$ ) dengan taraf signifikansi $95 \%(\alpha<0,05)$ untuk mengetahui apakah ada perbedaan yang signifikan antara kelompok perlakuan. Bila hasil uji analisis tersebut terdapat perbedaan yang signifikan, analisis dilanjutkan dengan uji Tukey untuk mengetahui adanya perbedaan antar kelompok (Priyatno, 2010).

\section{Hasil dan Pembahasan}

Determinasi tanaman menunjukkan bahwa tanaman yang digunakan adalah ketapang (Terminalia catappa L.) yang berasal dari keluarga Combretaceae. Hasil determinasi dari "Laboratorium Mamalogi" Bidang Zoologi, Pusat Penelitian Biologi-LIPI Cibinong menyatakan bahwa hewan yang digunakan adalah hamster syrian (Mesocricetus auratus).

Proses ekstraksi daun ketapang menggunakan metode maserasi. Keuntungan metode ini ialah kerusakan atau degradasi metabolit dapat diminimalisir karena proses perendamannya pada suhu kamar (Hanani, 2015). Metode maserasi ini menggunakan etanol
$70 \%$ sebagai pelarut. Alasan digunakan etanol $70 \%$ sebagai pelarut karena lebih selektif terhadap senyawa yang akan ditarik, kapang dan bakteri tidak mudah tumbuh dan dapat menguap dengan suhu rendah yang akan memudahkan saat pemekatan. Selain itu dalam etanol $70 \%$ terdapat $30 \%$ air yang diharapkan berguna untuk pembasahan pada simplisia sehingga zat penyari mudah masuk ke dalam dinding sel simplisia. Maserasi dilakukan secara berulang dengan menggunakan cairan penyari yang baru untuk menghindari jenuhnya cairan penyari sehingga proses penyarian lebih sempurna, selain itu senyawa aktif pada simplisia diduga masih ada, sehingga dilakukan remaserasi dengan tujuan setelah melewati proses remaserasi senyawa aktif sudah tidak ada.

Maserat yang diperoleh selanjutnya dipekatkan dengan menggunakan vacuum rotary evaporator dengan suhu $50^{\circ} \mathrm{C}$. Pemekatan dilakukan dengan tujuan untuk memisahkan ekstrak dari cairan penyarinya, sehingga didapatkan konsentrasi yang lebih besar. Prinsip dari vacuum rotary evaporator adalah pemisahan ekstrak dari cairan penyari dengan pemanasan dan penurunan tekanan dengan memutarkan labu saat pemanasan. Hasilnya didapatkan ekstrak kental yang masih mengandung air, kemudian dilakukan pengeringan untuk mengurangi kadar air di waterbath dengan suhu $50^{\circ} \mathrm{C}$. Hasil ekstrak kental daun ketapang yang diperoleh sebanyak I52,32 g dapat dilihat pada Tabel I.

Tabel I. Hasil Ekstraksi Ekstrak Etanol 70\% Daun Ketapang

\begin{tabular}{clc}
\hline No. & \multicolumn{1}{c}{ Jenis } & Bobot $(\mathrm{g})$ \\
\hline I. & Daun Ketapang Segar & 6000 \\
2. & Serbuk Daun Ketapang & 750 \\
3. & Ekstrak Etanol 70\% & I52,32 \\
& Kental & \\
\hline
\end{tabular}

Untuk mengetahui kualitas dari ekstrak daun ketapang, maka dilakukan pemeriksaan karakteristik ekstrak. Dari pemeriksaan organoleptis, didapatkan ekstrak dengan bentuk cairan kental, bau khas, rasa khas dan berwarna cokelat. Hasil pemeriksaan organoleptis dapat dilihat pada Tabel 2.

Tabel 2. Hasil Uji Organoleptis Ekstrak Etanol 70\% Daun Ketapang

\begin{tabular}{cccccc}
\hline \multirow{2}{*}{ No. } & \multirow{2}{*}{ Jenis } & \multicolumn{4}{c}{ Uji Organoleptis } \\
\cline { 3 - 6 } & & Bentuk & Bau & Rasa & Warna \\
\hline I. & Serbuk & Agak & Khas & Pahit & $\begin{array}{c}\text { Hijau } \\
\text { tua }\end{array}$ \\
2. & Ekstrak & Kental & Khas & Khas & Coklat \\
\hline
\end{tabular}


Penetapan kadar air bertujuan untuk mengetahui besarnya kandungan air di dalam bahan uji dan juga untuk menghindari percepatan pertumbuhan mikroba dalam ekstrak, juga untuk menjaga kualitas ekstrak. Hasil kadar air yang didapat yaitu sebesar 6,75\%. Kadar abu merupakan indikator terhadap cemaran bahan anorganik. Hasil kadar abu yang didapat yaitu $5,06 \%$. Rendemen dihitung untuk mengetahui persentase zat yang didapat setelah dilakukan proses ekstraksi. Hasil rendemen yang diperoleh dari ekstrak sebesar 20,30\% yang dapat dilihat pada Tabel 3.

Tabel 3. Hasil Rendemen, Kadar Air dan Kadar Abu Ekstrak Etanol 70\% Daun Ketapang

\begin{tabular}{clc}
\hline No. & \multicolumn{1}{c}{ Parameter } & Hasil $(\%)$ \\
\hline I. & Rendemen & 20,30 \\
2. & Kadar Air & 6,75 \\
3. & Kadar Abu Total & 5,06 \\
\hline
\end{tabular}

Penapisan fitokimia ekstrak dilakukan untuk mengetahui atau mengidentifikasi kandungan kimia yang terdapat pada ekstrak etanol 70\% daun ketapang. Berikut data yang diperoleh:

Tabel 4. Penapisan Fitokimia Ekstrak Etanol 70\% Daun Ketapang

\begin{tabular}{clc}
\hline No. & \multicolumn{1}{c}{ Pengujian } & Hasil \\
\hline I. & Alkaloid & + \\
2. & Flavonoid & + \\
3. & Saponin & + \\
4. & Fenol & + \\
5. & Tanin & + \\
6. & Triterpenoid & + \\
7. & Steroid & -
\end{tabular}

Keterangan : (+) menyatakan positif mengandung senyawa yang diidentifikasi dan (-) menyatakan negatif mengandung senyawa yang diidentifikasi.

Pemeriksaan kandungan kimia dilakukan untuk mengidentifikasi senyawa-senyawa yang terdapat di dalam ekstrak etanol 70\% daun ketapang. Hasil uji penapisan fitokimia menunjukkan adanya senyawa alkaloid yang ditandai terbentuknya endapan putih pada pereaksi mayer dan terbentuknya endapan berwarna merah pada pereaksi dragendorff, senyawa flavonoid ditandai dengan terbentuknya warna merah hingga merah lembayung, senyawa saponin ditandai dengan terbentuknya busa, senyawa fenol ditandai dengan terbentuknya warna biru hingga kehitaman, senyawa tanin ditandai dengan terbentuknya endapan putih, dan senyawa terpenoid ditandai dengan terbentuknya warna merah. Senyawa flavonoid berperan terhadap penurunan kadar kolesterol total dan LDL. Flavonoid menyebabkan penghambahatan sintesis kolesterol, sintesis esterifikasi kolesterol, dan menghambat aktivitas HMG-CoA reduktase (Metwally et al., 2009). Mekanisme saponin dalam mengurangi kolesterol dalam tubuh dengan menghambat reabsorbsi dan meningkatkan ekskresi (Egbung et al., 2009). Mekanisme tanin sebagai antihiperkolesterolemia adalah dengan cara menghambat adipogenesis dan menghambat absorbsi lemak di intestinal (Kumari, 2012).

Pemeriksaan kadar kolesterol total dan LDL darah hamster dilakukan sebanyak dua kali. Pertama pada hari ke-36, yaitu setelah pemberian pakan tinggi kolesterol selama 28 hari dan setelah induksi aloksan yang dilakukan pada hari ke-32. Pemeriksaan pertama ini dilakukan untuk mengetahui kadar kolesterol total dan LDL darah sudah dalam kondisi hiperkolesterolemia dan hiperglikemia. Pemeriksaan kedua dilakukan pada hari ke-5I, yaitu setelah pemberian ekstrak etanol $70 \%$ daun ketapang selama I4 hari. Pemeriksaan kedua ini dilakukan untuk mengetahui besar penurunan kadar kolesterol total dan LDL darah setelah pemberian ekstrak etanol 70\% daun ketapang.

Pemilihan hamster syrian jantan (Mesocricetus auratus) yang berumur 3-4 bulan dimaksudkan hamster dengan umur tersebut sudah bisa dikatakan sebagai hamster dewasa, sehingga diharapkan memiliki kesamaan dengan manusia dimana penyakit kolesterol lebih dominan terdapat pada manusia dewasa. Jenis kelamin jantan dipilih karena hamster jantan lebih dominan tidak dipengaruhi oleh perubahan hormon, sehingga diharapkan dapat memberikan hasil penelitian yang stabil.

Setelah hamster dinyatakan hiperkolesterolemia dan hiperglikemia, selanjutnya dilakukan pengecekan kadar awal kolesterol total dan LDL. Kemudian hamster diberikan perlakuan sesuai dengan kelompok uji selama I4 hari (hari ke-37 sampai hari ke-50). Setelah pemberian ekstrak dilakukan pemeriksaan kadar kolesterol total dan LDL akhir. Pada penelitian ini terdapat 6 kelompok perlakuan uji, diantaranya kontrol normal, kontrol positif, kontrol negatif, Kontrol Uji I (KU I), Kontrol Uji II (KU II), dan Kontrol Uji III (KU III). Kontrol normal hanya diberikan pakan standar yang bertujuan untuk mengetahui kadar normal kolesterol dan LDL pada hamster. Pada kontrol 
positif diberikan obat pembanding yaitu atorvastatin. Penggunaan atorvastatin diharapkan dapat memberikan penurunan signifikan yang digunakan sebagai pembanding zat uji. Kontrol negatif, kelompok ini berguna untuk mengetahui faktor-faktor lain yang dapat menyebabkan penurunan kolesterol total dan LDL darah pada hamster. Kontrol Uji I, II, dan III merupakan kelompok uji yang diberikan bahan uji dengan masing-masing kelompok mendapatkan dosis yang berbeda. Semua kelompok perlakuan, kecuali kelompok normal diberi pakan tinggi lemak selama 28 hari. Pakan tinggi lemak diberikan supaya hewan uji mengalami keadaan hiperkolesterolemia, sedangkan induksi aloksan akan memberi efek kerusakan pada sel-sel $\beta$ pankreas. Kerusakan sel $\beta$ pankreas ini dapat mengakibatkan sekresi insulin menurun, sehingga dapat mengakibatkan keadaan hiperglikemia pada hewan uji (Szukudelski, 200I).

Persentase penurunan kadar kolesterol total dapat dilihat pada Gambar I bahwa persen ratarata penurunan terbesar pada kelompok kontrol positif yaitu sebesar 68,74\%. Dibandingkan dengan KU I, II, III, dan kontrol negatif secara berturut-turut yaitu 31,07\%, 43,09\%, 59,02\% dan $-6,88 \%$.

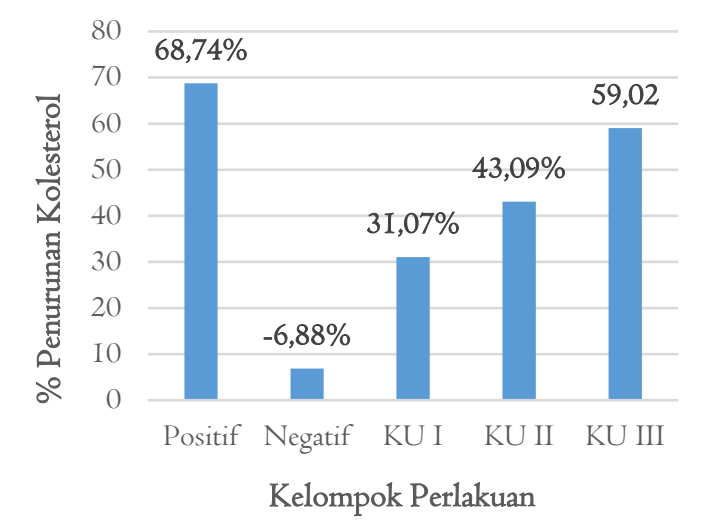

Gambar I. Persentase penurunan kadar kolesterol total.

Tahap selanjutnya dilakukan pengambilan darah akhir pada hari ke-5I untuk melihat penurunan kadar kolesterol total dan LDL setelah diberikan perlakuan uji. Sebelum pengambilan darah semua hamster dipuasakan terlebih dahulu selama \pm 12 jam dengan tujuan agar kadar kolesterol total dan LDL yang didapat tidak dipengaruhi oleh makanan yang dikonsumsi hamster. Pengambilan darah dilakukan pada bagian sinus orbital, hal tersebut dikarenakan jumlah darah yang didapat lebih banyak. Hamster dibius dengan ketamin hingga tidak sadarkan diri, pengambilan darah menggunakan pipa kapiler yang ditusukkan pada sudut mata hamster sampai darah mengalir, kemudain darah ditampung ke dalam microtube. Darah tersebut selanjutnya disentrifugasi selama 5 menit dengan kecepatan $6000 \mathrm{rpm}$ untuk memperoleh serum darah. Kemudian serum yang diperoleh digunakan untuk mengukur kadar kolesterol total dan LDL darah menggunakan fotometer klinikal.

Hasil pemeriksaan kadar kolesterol total dan LDL kemudian dihitung persentase penurunannya untuk diuji statistik menggunakan ANOVA satu arah. Data yang diperoleh sebelumnya diuji normalitas dan homogenitas untuk mengetahui data sudah terdistribusi merata. Hasil statistik analisis varians (ANOVA) satu arah menunjukkan semua dosis ekstrak etanol $70 \%$ daun ketapang memiliki aktivitas menurunkan kadar kolesterol total dan LDL darah $(p=0,000(<0,05))$. Selanjutnya dilakukan uji Tukey untuk mengetahui adanya perbedaan bermakna antar kelompok perlakuan. Uji Tukey menunjukkan perbedaan bermakna antara kontrol positif dengan kontrol negatif dan kontrol uji I, II, dan III.

Persentase penurunan kadar LDL dapat dilihat pada Gambar 2 bahwa rata-rata persen penurunan terbesar kadar LDL yaitu pada kelompok kontrol positif yaitu sebesar 70,34\%. Dibandingkan dengan KU I, KU II, KU III dan kontrol negatif secara berturut-turut yaitu 33,07\%, 40,82\%, 58,94\% dan -I I,I6\%.

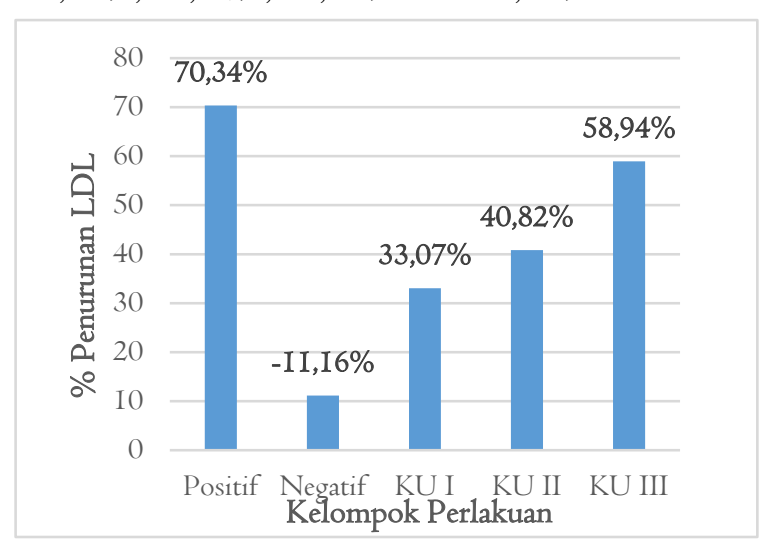

Gambar 2. Rata-rata Persentase Penurunan Kadar LDL.

Dalam hal ini menunjukkan kelompok ekstrak etanol 70\% daun ketapang (KU I, KU II, dan KU III) mempunyai aktivitas yang dapat menurunkan kadar kolesterol total, akan tetapi tidak lebih baik jika dibandingkan dengan kontrol positif atorvastatin yang mampu menurunkan kadar kolesterol total sebesar 68,74\%. Persentase penurunan kadar kolesterol total KU I sebesar 3I,07\%, KU II sebesar 
43,09\%, dan KU III sebesar 59,02\%. Dapat dilihat bahwa KU III memiliki aktivitas lebih besar dibandingkan dengan KU I dan KU II, namun tidak sebanding dengan kontrol positif atorvastatin. Pada hasil penurunan LDL, hasil uji Tukey menunjukkan perbedaan bermakna antara kontrol positif, negatif, dan KU III, namun tidak ada perbedaan bermakna antara KU I dan KU II. Dalam hal ini menunjukkan kelompok ekstrak etanol 70\% daun ketapang (KU I, KU II, dan KU III) mempunyai aktivitas yang dapat menurunkan kadar LDL, akan tetapi tidak lebih baik jika dibandingkan dengan kontrol positif atorvastatin yang mampu menurunkan kadar LDL sebesar 70,34\%. Persentase penurunan kadar LDL KU I sebesar 33,07\%, KU II sebesar 40,82\%, dan KU III sebesar 58,94\%. Dapat dilihat bahwa pemberian KU III memiliki aktivitas lebih besar dibandingkan dengan KU I dan KU II, namun tidak sebanding dengan kontrol positif atorvastatin.

Data dianalisa menggunakan analisis varians (ANOVA) satu arah untuk mengetahui adanya pengaruh atau perbedaan bermakna pada persentase penurunan kolesterol total dan LDL setelah perlakuan. Hasil analisa menunjukkan $\mathrm{p}=0,000(<0,05)$. Hasil tersebut menunjukkan adanya aktivitas ekstrak etanol $70 \%$ daun ketapang terhadap penurunan kadar kolesterol total dan LDL. Selanjutnya dilakukan uji Tukey untuk mengetahui adanya perbedaan bermakna antar kelompok perlakuan. Hasil uji Tukey menunjukkan adanya perbedaan bermakna di setiap kelompok dalam menurunkan kadar kolesterol total sedangkan pada pemeriksaan LDL menunjukkan adanya perbedaan bermakna di setiap kelompok, kecuali pada KU I dan KU II.

\section{Simpulan dan Saran}

Berdasarkan penelitian yang dilakukan dapat disimpulkan bahwa semua dosis ekstrak etanol 70\% daun ketapang (Terminalia catappa L.) memiliki aktivitas menurunkan kolesterol total dan LDL. Pada KU III (Dosis I20 mg/Kg BB) dinyatakan mampu menurunkan kadar kolesterol total dan LDL yang tertinggi dengan persentase penurunan masing-masing sebesar 59,02\% dan $58,94 \%$ namun masih belum sebanding dengan kontrol positif (atorvastatin) yang mampu menurunkan kadar kolesterol total dan LDL dengan persentase penurunan masing-masing $68,74 \%$ dan $70,34 \%$.

\section{Daftar Pustaka}

Dachriyanus, Delpa OK, Rika O, Olivia E, Suhatri, M. Husni M. (2007). Uji Efek A-Mangostin terhadap Kadar Kolesterol Total, Trigliserida, Kolesterol HDL, dan Kolesterol LDL Darah Mencit Putih Jantan serta Penentuan Lethal Dosis 50 ( Ld 50). Jurnal Sains dan Teknologi Farmasi. I2 (2) : 65

Departemen Kesehatan RI. (1985). Cara Pembuatan Simplisia. Depkes RI. Jakarta. Hlm. 7-I5.

Departemen Kesehatan RI. (2008). Farmakope Herbal Indonesia. Direktorat Jendral Pengawasan Obat dan Makanan. Jakarta. Hlm. XXV, I69.

Divya N, Vijaya Anand A. phytochemical investigation and in vitro anti-diabetic activity of Terminalia catappa leaves. Int J Phyto Pharm. 2014;4:132-4.

Dwisari F, Harlia, Andi HA. (2016). Isolasi dan Karakterisasi Senyawa Terpenoid Ekstrak Metanol Akar Pohon Kayu Buta-buta (Excoecaria agallocha L.). JKK. Universitas Tanjungpura. 5 (3): 26.

Egbung GE, Essien EU, Itam EH, Onouha AR. (2010). The Effect Saponin Consumption on Cholesterol Metabolism in Wistar Albino Rats. Research Journal of Agriculture and Biological Sciences. 6 (6): I07 I-I073.

Federer, W. (1963). Experimental Design Theory and Application. Oxford: Oxford and Lbh Publish Hinco.

Guyton AC, Hall JE. (2008). Buku Ajar Fisiologi Kedokteran. Edisi I I. EGC. Jakarta. Hlm. 324-375.

Hanani E. (2015). Analisis Fitokimia. Buku Kedokteran EGC. Jakarta. Hlm. IO, I I, I3, 75, 87, I I4, I52, 236.

Istiqomah S. (2016). Pengaruh Ekstrak Daun Ketapang (Terminalia catappa L.) Terhadap Berat Badan dan Kadar Glukosa Darah Puasa Mencit (Mus musculus) Diabetik. Skripsi. Fakultas Sains dan Teknologi Universitas Airlangga. Surabaya.

Katzung BG. (2012). Farmakologi Dasar dan Klinik Vol.2. Edisi 12. EGC. Jakarta.

Kinoshita, Inoue Y, Nakama S, Ichiba T, Aniya Y. Antioxidant and hepatoprotective actions of medicinal herb, Terminalia catappa L. from Okinawa Island and its 
tannin corilagin. Phytomedicine Journal.. 2006; I4(II):755-62. 12.

Kumari M, Jain S. (2012). Tannins: An Antinutrient With Positive Effect to Manage Diabetes. Research Journal of Recent Sciences. I (2) : 70-73.

Metwally MAA, El-Gellal AM, El-Sawaisi SM. (2009). Effects of Silymarin on Lipid Metabolism In Rats. World Applied Sciences Journal 6 (I2) : I634-I637.

Pirade PF. (20I5). Perbandingan Pengaruh Anestesi Ketamin-Xylazin dan KetaminZoletil Terhadap Fisiologi Kucing Lokal (Felis domestica). Skripsi. Program Studi Kedokteran Hewan. Fakultas Kedokteran Universitas Hasanuddin. Makassar.

Purwantini NM. (20I5). Uji Aktifitas Antihiperkolesterol Ekstrak Etanol 70\% Tempe Kacang Hijau pada Hamster Kolesterolemia Berdasarkan Kadar LDL dan Kolesterol Total. Skripsi. Fakultas Farmasi dan Sains Universitas Muhammadiyah Prof.DR.Hamka. Jakarta. Hlm. I4-I5.

Priyanto. (2009). Farmakoterapi dan Teknologi Medis. Leskonfi. Depok. Hlm. I65.

Priyatno D. (2010). Paham Analisa Statistik Data dengan SPSS. MediaKom. Yogyakarta. Hlm. 7I-76.

Reagan-Shaw S, Nihal M, Ahmad N. (2007). Dose Translation from Animal to Human Studies Revisited. The FASEB Journal. 22: 660.

Rowe CR, Sheskey PJ, Quinn ME. (2009). Handbook of Pharmaceutical Excipients Sixth Edition. Pharmaceutical Press and American Pharmacists Association. USA. Hlm. II9.

Suhono B. (2010). Ensiklopedia Flora Jilid V. PT.Kharisma Ilmu. Bogor. Hlm. I52

Szukudelski T. (200I). The Mechanism of Alloxan and Streptozotocin Action in B Cells of the Rat Pancreas. Journal of Physiological Research. Vol. 50. Hlm. 538.

Uttra KM, Bikha RD, Syed ZAS, Tarachand D, Thanwar D, Samar R. Lipid Profile of Patients With Diabetes Mellitus (A Multidisciplinary Study). World Applied Sciences Journal. I2 (9).

Vogel HG. (2008). Drug Discovery and Evaluation Pharmacological. Springer. USA. Hlm. 1674.
Waluyo Joko, Dwi Wahyuni. (2017). The Effect of Ketapang Leaf Extracts (Terminalia catappa L.) on The Cholesterol Levels of Male Mice (Mus musculus L.) Hypercholesterolemia. International Journal of Advanced Engineering Research and Science. 4 (7): 45-48. 